\title{
Terraced Pasture Changes the Soil Moisture Dynamics
}

\author{
Vanessa Schiavon Lopes ${ }^{1}$, Irene Maria Cardoso ${ }^{1}$, Osmar Rosa Fernandes ${ }^{1}$, Raphael Bragança Alves Fernandes ${ }^{1}$, \\ Paulo Roberto Cecon ${ }^{2}$, Lucas de Carvalho Gomes ${ }^{1} \&$ José Maria Rodrigues da Luz ${ }^{3}$ \\ ${ }^{1}$ Departamento de Solos, Universidade Federal de Viçosa, Viçosa, Minas Gerais, Brazil \\ ${ }^{2}$ Departamento de Estatística, Universidade Federal de Viçosa, Viçosa, Minas Gerais, Brazil \\ ${ }^{3}$ Programa de Pós-graduação em Bioquímica e Biologia Molecular, Universidade Federal de Alagoas, Maceió, \\ AL, Brazil \\ Correspondence: Irene Maria Cardoso, Departamento de Solo, Universidade Federal de Viçosa, Viçosa, Minas \\ Gerais, Brazil. E-mail: irene@ufv.br \\ José Maria Rodrigues da Luz, Programa de Pós-graduação em Bioquímica e Biologia Molecular, Universidade \\ Federal de Alagoas, Maceió, AL, Brazil. E-mail: josemarodrigues@yahoo.com.br
}

Received: April 17, 2019

doi:10.5539/jas.v11n14p96
Accepted: June 7, 2019 Online Published: August 31, 2019

URL: https://doi.org/10.5539/jas.v11n14p96

\begin{abstract}
Climate changes, loss of biodiversity, soil degradation, scarcity and pollution of waters are the problems caused and experienced by society. The conservation methods of soil moisture are important for plant growth and groundwater preservation. The aim at this study was to evaluate the impacts of the terraces on soil moisture and to analyze the efficiency of Ground Penetration Radar (GPR) in the soil moisture determination. Soil moisture was determined by gravimetric and GPR methods in the depths of 0 to 10,10 to 30,30 to 60 and, 60 to $100 \mathrm{~cm}$. The water storage in depth was larger and uniform in terraced than in the non-terraced pasture. However, the non terraced pasture has less soil compaction. Thus, the terrace does not guarantee adequate pasture management and other alternatives for sustainable management of cattle and reduction of soil compaction is necessary. The GPR method may be used to estimate the soil water content in volumetric basis in the field of a non-invasive manner. However, there need to study and determine the accuracy in GPR measurement in different methods and soil types.
\end{abstract}

Keywords: livestock, water infiltration, deforestation, anthropic activities, ground penetration radar

\section{Introduction}

The scarcity of freshwater is a threat to the human being (Mekonnen \& Hoekstra, 2016). About $71 \%$ of the world's population, 4.3 billion people, live with moderate to severe water scarcity for at least one month in the year (Mekonnen \& Hoekstra, 2016). Brazil has the largest freshwater reserve in the world, but the scarcity of this natural resource, especially in the urban area, has been observed.

This scarcity could be due because the impacts of anthropic activities on the biogeochemical cycles (Germer et al., 2009). For instance, the deforestation for pastures formation changes the water cycle (Nepstad et al., 2006), because, very often, livestock rapidly degrades pasture and modify the infiltration and runoff of water (Zimmermann et al., 2006). This degradation influences soil quality, for it reduces plant cover and organic matter (Shang et al., 2014) and increases soil compaction (Mwendera \& Saleem, 1997). The loss of plant cover changes the wetting and drying cycles of the soil and increases the crusts formation by rainfall impacts (Gomes et al., 2012). The low organic matter content has a negative impact on the living beings of the soil and soil porosity (Savadogo et al., 2007). The reduction of soil porosity leads to the reduction of water infiltration and to the increase of water runoff, soil erosion, and silting of the rivers, among other negative impacts (Galdino et al., 2015)

The Woods Zone in region of the Minas Gerais state, Brazil, the deforestation for coffee and pasture production led to soil degradation and loss of water quality and quantity. The negative impacts of the anthropic activity on soils and rivers were intensified by frequent climate changes. To mitigate the problems, terraces have been suggested to be implemented on pasture (Galdino et al., 2015; Zhang et al., 2017; Chen et al., 2017). 
The terraces are considered to increase water infiltration in the soil (Fu et al., 2003) and the consequence is water availability in springs (Power, 2010; Lu et al., 2017). However, the impacts of terraces on soil moisture have been little investigated. Furthermore, soil moisture determination is limited by heterogeneity in the spatial and temporal distribution of water and by the lack of a standard method (Dobriyal et al., 2012).

Time domain reflectometry (TDR) and gravimetric methods are not suitable for in situ conditions since they alter the physical structure of soil (Dobriyal et al., 2012). Furthermore, these methods are invasive.

Currently, Ground Penetration Radar (GPR) has been proposed as an alternative for determination of soil moisture. GPR is not an invasive method and has a quick estimate of water content. In addition, this method has a high lateral resolution that allows a better determination of the variability of the water content variations in a field (Huisman et al., 2001; Grote et al., 2003; Dobriyal et al., 2012; Lu et al., 2017).

The general objective of this study was to evaluate the impacts of the terraces on soil moisture of a pasture. Specifically, the relationship of temporal dynamics soil moisture in depth and the efficiency of the GPR in soil moisture determination by the gravimetric method were analyzed.

\section{Materials and Methods}

This study was carried out in the municipality of Coimbra $\left(20^{\circ} 49^{\prime} 19.2^{\prime \prime} \mathrm{S}\right.$ and $\left.42^{\circ} 47^{\prime} 51.9^{\prime \prime} \mathrm{W}\right)$, Minas Gerais state, Brazil that is located on the Atlantic Forest domain, the fifth hotspot of biodiversity, on the crystalline basement, composed by gneiss rocks. The dominant relief is strong undulating and mountainous, with slopes of convex-concave profile and flat bottoms of the valleys. The yellow-red Oxisol is the predominant soil. At average temperature is $20{ }^{\circ} \mathrm{C}$ and average rainfall is $1283 \mathrm{~mm}$ (Climate-Data.Org). Rainfall occurs with high frequency from November to March. The rainfall occurred in the period of the experiment (from January to August, 2017), is presented in Figure 1. During the study time, accumulated rainfall was $542 \mathrm{~mm}$, with higher amounts in February and March.

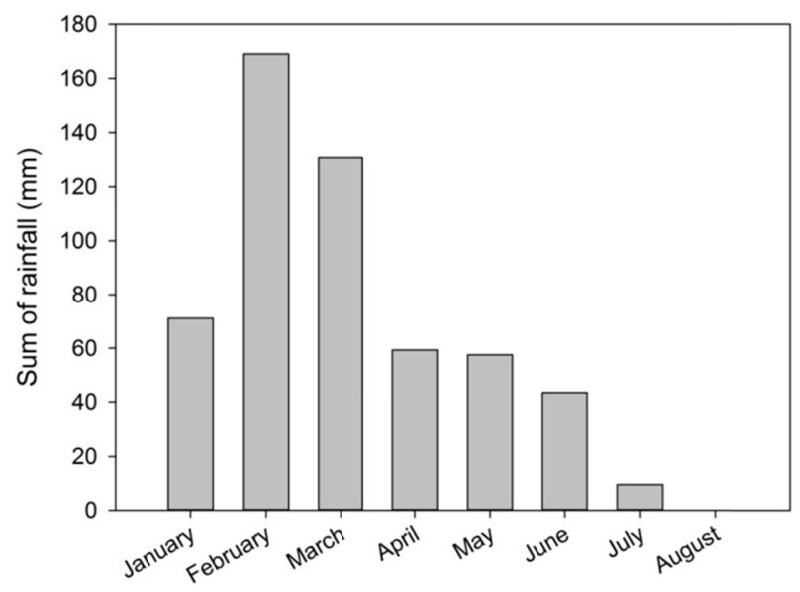

Figure 1. Sum of rainfall in Coimbra, Minas Gerais (Brazil), 2017

Coimbra municipality is located in the Turvo Sujo watershed. This river is Sweet River tributary, which recently suffered an environmental crime because of the rupture of the Iron Mining Dam in Mariana (Minas Gerais). The main activity is agriculture, carried out mainly by family farmers. The crops are diversified but the main cash activity is dairy cattle, raised on extensive pasture. The grass is mainly Brachiaria sp, cultivated in monoculture, without fertilizers. In the analyzed pasture the cattle (15 units) is created loose. In this property were built three terraces with spaced $20 \mathrm{~m}$ of each other, located in a slope of $19^{\circ}$. The terraces were done in contour line by a crawler tractor, in 2015. The three terraces were of the Nichols type with narrow bases and non-parallel.

This area was divided into two parts, one part with terrace (Ter) and one part without terrace (NTer). The two parts were parallel, on the same slope, the same face of sun exposure and the same soil type. Six equidistant transects of $10 \mathrm{~m}$ each were marked on the pastures (three on the Ter and three on the NTer) (Figure2). 


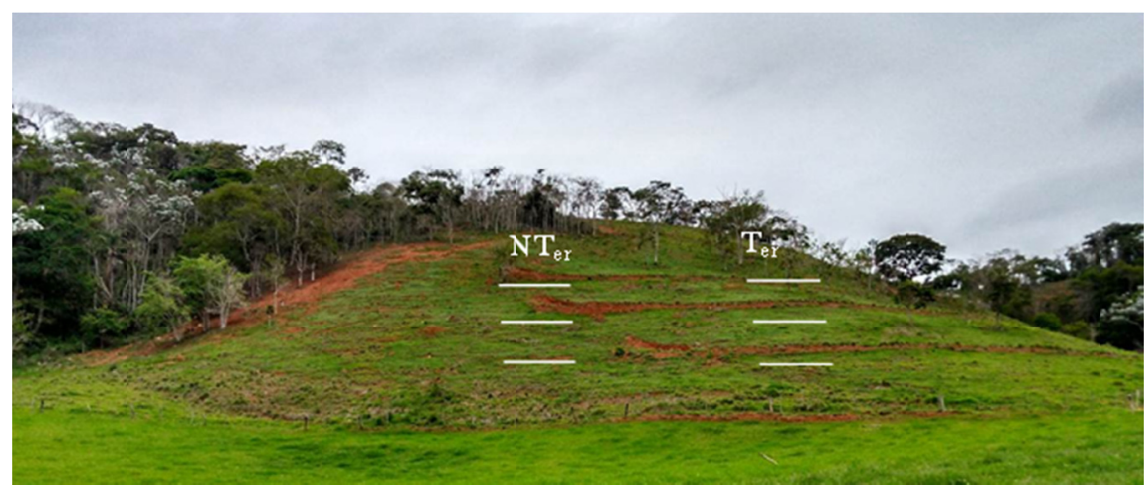

Figure 2. Pasture terraced (Ter) and non-terraced (NTer), in Coimbra, Minas Gerais state, Brazil. The white lines represent the six transects of $10 \mathrm{~m}$, where soil sampling was done

\subsection{Analyzes of Soil Physical Properties}

The soil sampling was done in three points equidistant, in each transect, and in four depths $(0-10,10-30,30-60$, 60-100 cm). We obtained 72 soil samples in the non-terraced pasture $\left(\mathrm{NT}_{\mathrm{er}}\right)$ and terraced pasture $\left(\mathrm{T}_{\mathrm{er}}\right)$.

Bulk density was determined using volumetric ring method; microporosity was determined using the tension table $(6 \mathrm{kPa})$ and the total porosity was the ratio between bulk density and particle density (equal 2.64). The hydraulic conductivity was done by constant load permeameter method. The granulometry was determined using pipette method with low rotation $(50 \mathrm{ppm})$ and sodium hydroxide $(0.1 \mathrm{~mol} / \mathrm{L})$ as a dispersant; the coarse and fine sand fractions were obtained by sieving and the silt and clay fractions via sedimentation (Embrapa, 2011). The soil of the study area, related to the texture, was classified as very clayey (Table 1), except the first depth of the $\mathrm{T}_{\text {er }}$ and $\mathrm{NT}_{\text {er }}$ that were clayey. The pipette method with low rotation was also used to determine the clay dispersed in water (Embrapa, 2011).

Table 1. Total organic carbon content (TOC), Textural analysis, and water dispersed clay (WDC) of the soil of terraced pasture $\left(\mathrm{T}_{\mathrm{er}}\right)$ and non-terraced pasture $\left(\mathrm{NT}_{\mathrm{er}}\right)$, Coimbra, Minas Gerais, Brazil

\begin{tabular}{|c|c|c|c|c|c|c|c|}
\hline Treatment & Soil depth & TOC & Thin sand & Coarse sand & Silt & Clay & WDC \\
\hline & $\mathrm{cm}$ & $\mathrm{g} \mathrm{kg}^{-1}$ & ---------'- & $\mathrm{kg} \mathrm{kg}^{-1}$ & ----- & ----- & $(\%)$ \\
\hline \multirow{2}{*}{$\begin{array}{l}\mathrm{T}_{\text {er }} \\
\mathrm{NT}_{\text {er }}\end{array}$} & \multirow{2}{*}{$0-10$} & 23.6 & 0.16 & 0.17 & 0.14 & 0.53 & 22.00 \\
\hline & & 20.5 & 0.12 & 0.18 & 0.11 & 0.59 & 19.00 \\
\hline \multirow{2}{*}{$\begin{array}{l}\mathrm{T}_{\text {er }} \\
\mathrm{NT}_{\text {er }}\end{array}$} & \multirow{2}{*}{$10-30$} & 15.7 & 0.12 & 0.13 & 0.13 & 0.61 & 27.00 \\
\hline & & 15.7 & 0.10 & 0.13 & 0.11 & 0.67 & 24.00 \\
\hline \multirow{2}{*}{$\begin{array}{l}\mathrm{T}_{\text {er }} \\
\mathrm{NT}_{\text {er }}\end{array}$} & \multirow{2}{*}{$30-60$} & 13.4 & 0.11 & 0.11 & 0.10 & 0.67 & 33.00 \\
\hline & & 13.7 & 0.08 & 0.10 & 0.11 & 0.72 & 31.00 \\
\hline \multirow{2}{*}{$\begin{array}{l}\mathrm{T}_{\mathrm{er}} \\
\mathrm{NT}_{\mathrm{er}}\end{array}$} & \multirow{2}{*}{$60-100$} & 12.0 & 0.13 & 0.12 & 0.12 & 0.64 & 12.80 \\
\hline & & 11.5 & 0.09 & 0.10 & 0.10 & 0.71 & 11.22 \\
\hline
\end{tabular}

Total organic carbon (TOC) was performed by the Walkley-Black method (Tedesco et al., 1995). The TOC (Table 1) was evaluated as medium, except for the depth of $0-10 \mathrm{~cm}$ of Ter that it was evaluated as good and for 60-100 $\mathrm{cm}$ of $\mathrm{NT}_{\text {er }}$ it was evaluated as low (Alvarez et al., 1999).

\subsection{Soil Moisture Determination}

Soil moisture was determined in the field by Ground Penetration Radar (GPR) method and in the laboratory by gravimetric method.

The determination was done in nine different days in the wet season and one day in the dry season. In this last season, soil moisture determination was performed after a long period without rainfall for effect of comparison. The sampling for soil moisture determination by gravimetric method was also performed on the same days.

Soil moisture determination by GPR: To determined soil moisture, we walked the $10 \mathrm{~m}$ transects with the Geophysical Survey Systems (GSSI) equipment, with a resolution of one meter. The GSSI had $400 \mathrm{MHz}$ 
shielded antenna, control unit and a portable computer for recording the radargrams. We used 512 dashes to get high signals and noises ratio and the best records of the field profiles. The radargrams were analyzed in the Radan 7 software. The dielectric constants were obtained by the hyperboles up to $100 \mathrm{~cm}$ depth.

The water content of the soil was performed by the Topp et al. (1980) and Roth et al. (1992) equations that use the dielectric constant.

Topp equation:

$$
\theta_{v}=-5,3 \cdot 10^{-2}+2,92 \cdot 10^{-2} \varepsilon_{r}-5,5 \cdot 10^{-4} \varepsilon_{r}^{2}+4,3 \cdot 10^{-6} \varepsilon_{r}^{3}
$$

and,

Roth equation:

$$
\theta_{v}=-7,8 \cdot 10^{-2}+4,48 \cdot 10^{-2} \varepsilon_{r}-1,95 \cdot 10^{-3} \varepsilon_{r}^{2}+3,61.10^{-5} \varepsilon_{r}^{3}
$$

In both equations, $\theta_{v}$ is the water content in volumetric basis and $\varepsilon_{r}$ is the dielectric constant.

\subsection{Soil Moisture Determination by Gravimetric Method}

For the determination of gravimetric moisture, 240 soil samples (simple deformed sample) were collected at depths of $0-10,10-30,30-60$ and $60-100 \mathrm{~cm}$, in the middle of the transects, during ten days. These samples were stored in aluminum cans (200 g capacity). In the laboratory, these cans with soil were weighed in an analytical balance before and after drying for 48 hours at $100-105^{\circ} \mathrm{C}$. Soil moisture by the difference of weigh.

Then, the soil volumetric water content and soil water storage within a $1 \mathrm{~m}$ depth were calculated by the Equations 3 and 4.

$$
\theta_{v}=\theta_{m} \cdot \rho
$$

In Equation 3, $\theta_{v}$ is average the water content in volumetric basis $(\mathrm{v} / \mathrm{v})$ and $\rho$ is means the bulk density $\left(\mathrm{g} / \mathrm{cm}^{3}\right)$.

$$
\theta_{s}=\theta_{v 1} \cdot 100+\theta_{v 2} \cdot 200+\theta_{v 3} \cdot 300+\theta_{v 4} \cdot 400
$$

This equation, $\theta_{\mathrm{v}}$ is the water content in the soil depths of 0 to $10\left(\theta_{\mathrm{v} 1}\right), 10$ to $30\left(\theta_{\mathrm{v} 2}\right), 30$ to $60\left(\theta_{\mathrm{v} 3}\right)$, and 60 to $100 \mathrm{~cm}\left(\theta_{v 4}\right)$.

The soil moisture change in the depths was determined by the ratio between the difference of moisture of 30-60 $\mathrm{cm}$ and $60-10 \mathrm{~cm}$ and moisture of $0-10 \mathrm{~cm}$ (Equation 5). The average of soil moisture in the pastures without and with terrace was used in this calculation.

$$
r_{1}=\left(\overline{\mathrm{X}}_{\mathrm{UMID}(30-60)}\right)-\left(\overline{\mathrm{X}}_{\mathrm{UMID}(0-10)}\right) /\left(\overline{\mathrm{X}}_{\mathrm{UMID}(0-10)}\right) \times 100
$$

and,

$$
r_{2}=\left(\overline{\mathrm{X}}_{\mathrm{UMID}(60-100)}\right)-\left(\overline{\mathrm{X}}_{\mathrm{UMID}(0-10)}\right) /\left(\overline{\mathrm{X}}_{\mathrm{UMID}(0-10)}\right) \times 100
$$

For the analysis of the relative variation of soil moisture between the dry and wet seasons in the two study areas, the $r_{3}$ ratio (Sun et al., 2013) was calculated by equation 6 .

$$
r_{3}=\left(\overline{\mathrm{X}}_{\mathrm{DC}}-\overline{\mathrm{X}}_{\mathrm{AC}}\right) /\left(\overline{\mathrm{X}}_{\mathrm{AC}}\right)
$$

In Equation 6, $\overline{\mathrm{X}}$ is the average of the soil moisture at each depth during (DC) and after (AC) the wet season.

\subsection{Analyze of the Efficiency of Ground Penetration Radar}

The comparison between soil volumetric moisture obtained by the Topp and Roth equations and volumetric method was performed using the mean squared error (MSE).

$$
\mathrm{MSE}=\sqrt{\frac{\sum_{\mathrm{i}=1}^{\mathrm{n}}\left(\mathrm{X}_{\mathrm{obs}, \mathrm{i}}-\mathrm{X}_{\text {model }, \mathrm{i}}\right)^{2}}{\mathrm{n}}}
$$

Where, $\mathrm{X}_{\mathrm{obs}, \mathrm{i}}=$ volumetric moisture of soil obtained by the gravimetric method; $\mathrm{X}_{\text {model, } \mathrm{i}}=$ volumetric moisture adjusted by regression analysis between volumetric moisture and moisture obtained by the Topp or Roth equations; $\mathrm{n}=45$ (number of observations).

\subsection{Statistical Analysis}

The descriptive analyzes and the $\mathrm{F}$ test at the 5\% level of significance were used to compare the means of bulk density, microporosity, macroporosity, hydraulic conductivity, volumetric moisture in the different soil depths, and water storage at one-meter depth.

The regression coefficients and t-test at the 5\% level of significance were used to evaluate the volumetric moisture determined by GPR. Statistical analyzes were performed using the SAEG program. 


\section{Results}

\subsection{Bulk Density, Microporosity, Macroporosity, and Hydraulic Conductivity of the Soils}

The terraced pasture had higher bulk density ( $\mathrm{p}<0.05$ ) (up to $17 \%$ ) in $10-30 \mathrm{~cm}$ and higher microporosity in $30-60$ and 60-100 cm soil depth than NTer (Table 2). However, the macroporosity was around 50\% higher in the $10-30 \mathrm{~cm}$ and $60-100 \mathrm{~cm}$ depth and hydraulic conductivity was $81 \%$ higher in the $10-30 \mathrm{~cm}$ depth in the non terraced pasture than in the terraced pasture.

Table 2. Bulk density, microporosity, macroporosity and hydraulic conductivity in different soil depths of a terraced pasture (Ter) and non-terraced (NTer) pasture

\begin{tabular}{|c|c|c|c|c|c|}
\hline Treatment & Soil depth & Bulk density & Microporosity & Macroporosity & Hydraulic conductivity \\
\hline \multirow{3}{*}{$\begin{array}{l}\mathrm{T}_{\mathrm{er}} \\
\mathrm{NT}_{\mathrm{e}}\end{array}$} & $\mathrm{cm}$ & $\mathrm{g} \mathrm{cm}^{-3}$ & ----------------- & b -------------------- & $\mathrm{cm} \mathrm{h}^{-1}$ \\
\hline & \multirow{2}{*}{$0-10$} & $1.38 \mathrm{a}( \pm 0.1)$ & $43.0 \mathrm{a}( \pm 0.03)$ & $6.0 \mathrm{a}( \pm 0.04)$ & $1.41 \mathrm{a}( \pm 3.14)$ \\
\hline & & $1.30 \mathrm{a}( \pm 0.09)$ & $46.0 \mathrm{a}( \pm 0.03)$ & $6.0 \mathrm{a}( \pm 0.06)$ & $3.79 \mathrm{a}( \pm 3.75)$ \\
\hline $\mathrm{T}_{\mathrm{er}}$ & \multirow{2}{*}{$10-30$} & $1.37 \mathrm{a}( \pm 0.07)$ & $45.0 \mathrm{a}( \pm 0.02)$ & $4.0 \mathrm{~b}( \pm 0.04)$ & $0.71 \mathrm{~b}( \pm 0.79)$ \\
\hline $\mathrm{NT}_{\text {er }}$ & & $1.20 \mathrm{~b}( \pm 0.1)$ & $42.0 \mathrm{a}( \pm 0.04)$ & $13.0 \mathrm{a}( \pm 0.06)$ & $3.73 \mathrm{a}( \pm 2.99)$ \\
\hline $\mathrm{T}_{\mathrm{er}}$ & \multirow{2}{*}{$30-60$} & $1.37 \mathrm{a}( \pm 0.03)$ & $46.0 \mathrm{a}( \pm 0.02)$ & $6.0 \mathrm{a}( \pm 0.06)$ & $3.41 \mathrm{a}( \pm 8.27)$ \\
\hline $\mathrm{NT}_{\text {er }}$ & & $1.15 \mathrm{~b}( \pm 0.11)$ & $41.0 \mathrm{~b}( \pm 0.05)$ & $12.0 \mathrm{a}( \pm 0.05)$ & $12.89 \mathrm{a}( \pm 12.9)$ \\
\hline $\mathrm{T}_{\mathrm{er}}$ & \multirow{2}{*}{$60-100$} & $1.32 \mathrm{a}( \pm 0.12)$ & $45.0 \mathrm{a}( \pm 0.03)$ & $8.0 \mathrm{~b}( \pm 0.05)$ & $2.30 \mathrm{a}( \pm 3.19)$ \\
\hline $\mathrm{NT}_{\text {er }}$ & & $1.10 \mathrm{~b}( \pm 0.05)$ & $41.0 \mathrm{~b}( \pm 0.02)$ & $17.0 \mathrm{a}( \pm 0.04)$ & $7.06 \mathrm{a}( \pm 6.12)$ \\
\hline
\end{tabular}

Note. In the columns, the averages followed of the same letter do not differ between the soil depths at the level of $5 \%$ of probability by the test $\mathrm{F}$. The values are the means of nine repetitions and a standard deviation $( \pm)$.

\subsection{Soil Moisture Determined by the Gravimetric Method}

Soil moisture varied between the Ter, NTer, and the soil depths (Figure 2). Only at 0-10 $\mathrm{cm}$ depth, the soil moisture in the two treatments was the same $(\mathrm{p}=0.05)$. In the other soil depths, Ter had higher soil moisture $(\mathrm{P}<$ 0.05 ) than NTer (Figure 2). In Ter, the relative variation of soil moisture was lower (on average 53\%) in 0 to 60 $\mathrm{cm}$ of depth than in NTer. Furthermore, in both treatments, the soil moisture varied more at the surface than in the other depths (Figure 2).

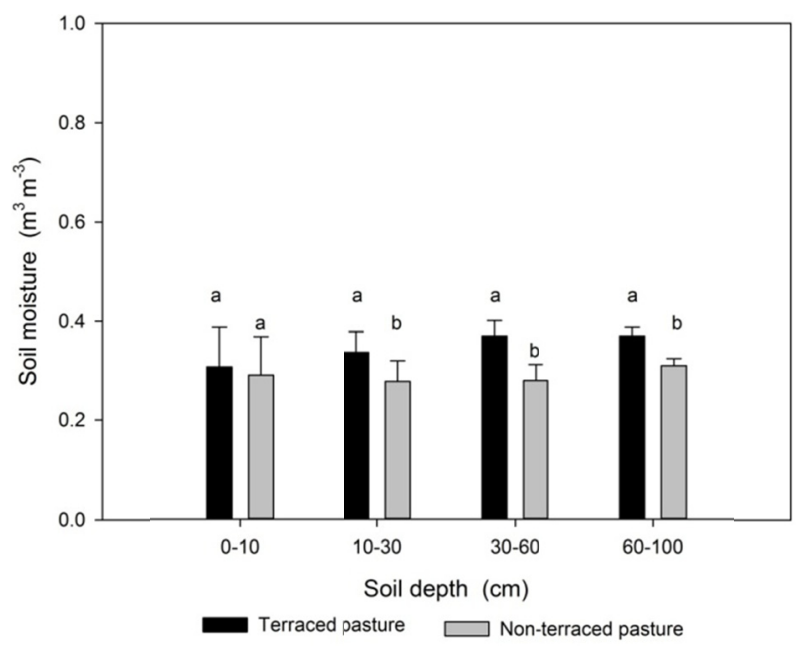

Figure 3. Soil moisture and relative variation of soil moisture in the different depths. The averages followed of the same letter do not differ between the soil depths at the level of $5 \%$ of probability by the test $\mathrm{F}$. The values are the means of 10 repetitions and a standard deviation

\subsection{Water Stored in One Meter of Soil Depth}

The water storage at $1 \mathrm{~m}$ soil depth (calculated by equation 3 ) was higher $(\mathrm{p}<0.05)$ in Ter than in NTer (Figure 4). In the non-terraced pasture, the soil moisture was $75 \%$ smaller than Ter. 


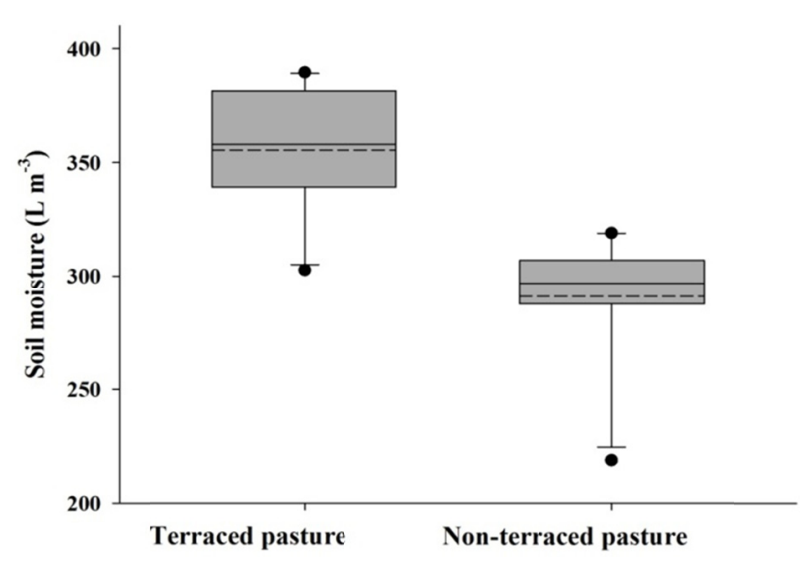

Figure 4. Soil moisture in one meter of soil depth. The continuous and dotted horizontal lines indicate the median and the average respectively

\subsection{Maintaining Soil Moisture in Depth}

The impact of the terrace on soil water maintenance at different soil depths was observed by soil moisture variation (equation 5, Figure 5). At 10 days of evaluation, soil moisture in Ter was higher (positive values) in the seventh $(30-60 \mathrm{~cm})$ and ninth $(60-100 \mathrm{~cm})$ day than in the surface. However, in NTer only in third $(30-60 \mathrm{~cm})$ and fifth $(60-100 \mathrm{~cm})$ days of evaluation, the soil moisture was higher than in the surface (Figure 5). The soil moisture in the depths of 30-60 and 60-100 cm was higher than at the soil surface in both treatments in August when there was no rainfall (Figures 1 and 5).

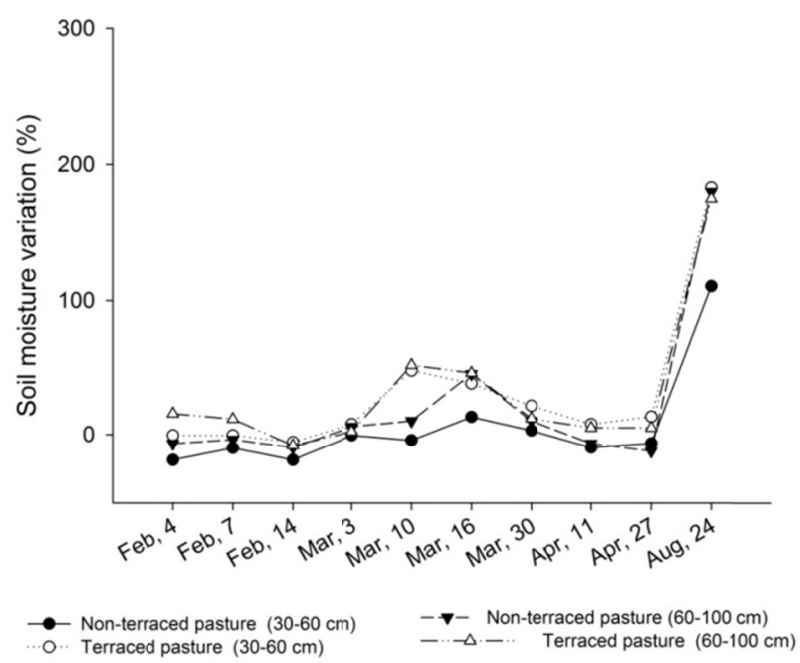

Figure 5. Variation of soil moisture (\%) between the depths of 30 to $100 \mathrm{~cm}$ and the surface $(0-10 \mathrm{~cm})$ in a terraced pasture and non-terraced. We performed the determination of the soil moisture in February (Feb), March (Mar), April (Apr) and August (Aug)

\subsection{Soil Moisture Dynamics in Depth}

The seasonal variations of soil moisture were similar between pastures and larger on the surface $(0-10 \mathrm{~cm})$ than other depths (Figure 6).

In the dry season, the average water storage in surface varied from 12 to $33 \%$ in the terraced area and from 10 to $32 \%$ in the non-terraced pasture. However, of 30 to $100 \mathrm{~cm}$, terraced pasture had higher soil moisture in the dry season than the other pasture in the wet season (Figure 6). In addition, pastures had lower variations of soil moisture in the wet season than dry season. 


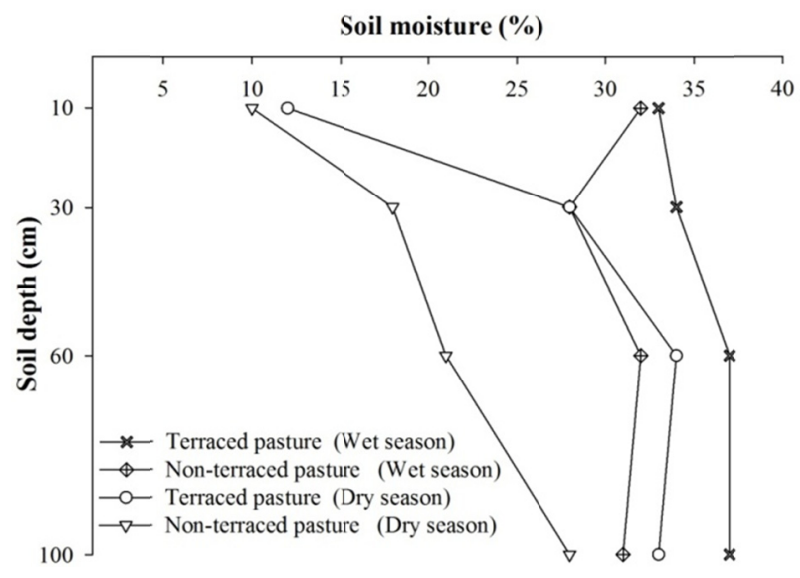

Figure 6. Soil moisture dynamics at different depths in a terraced pasture and non-terraced during the wet and dry season

\subsection{Soil Moisture Determined by GPR}

In this study, we obtained radargamas reflection hyperboles only in the soil depths greater than $10-30 \mathrm{~cm}$. The dielectric constants were obtained using values these hyperboles.

The GPR method had a high precision in determining the soil moisture when compared to the gravimetric method. The mean square error of GPR ranged from 0.019 to 0.026 (Figure 7). Thus, the estimates of soil moisture by the Topp and Roth equations were adequate. Furthermore, the relative error was similar between these equations (Figure 8). The highest peaks of this error were between the $15^{\text {th }}$ and $23^{\text {rd }}$ points in the Topp equation.

Soil moisture was lower in the non-terraced pasture than in terraced pasture (Figure 7). However, no difference in GPR efficiency between pastures was observed (Figures 7 and 8). 


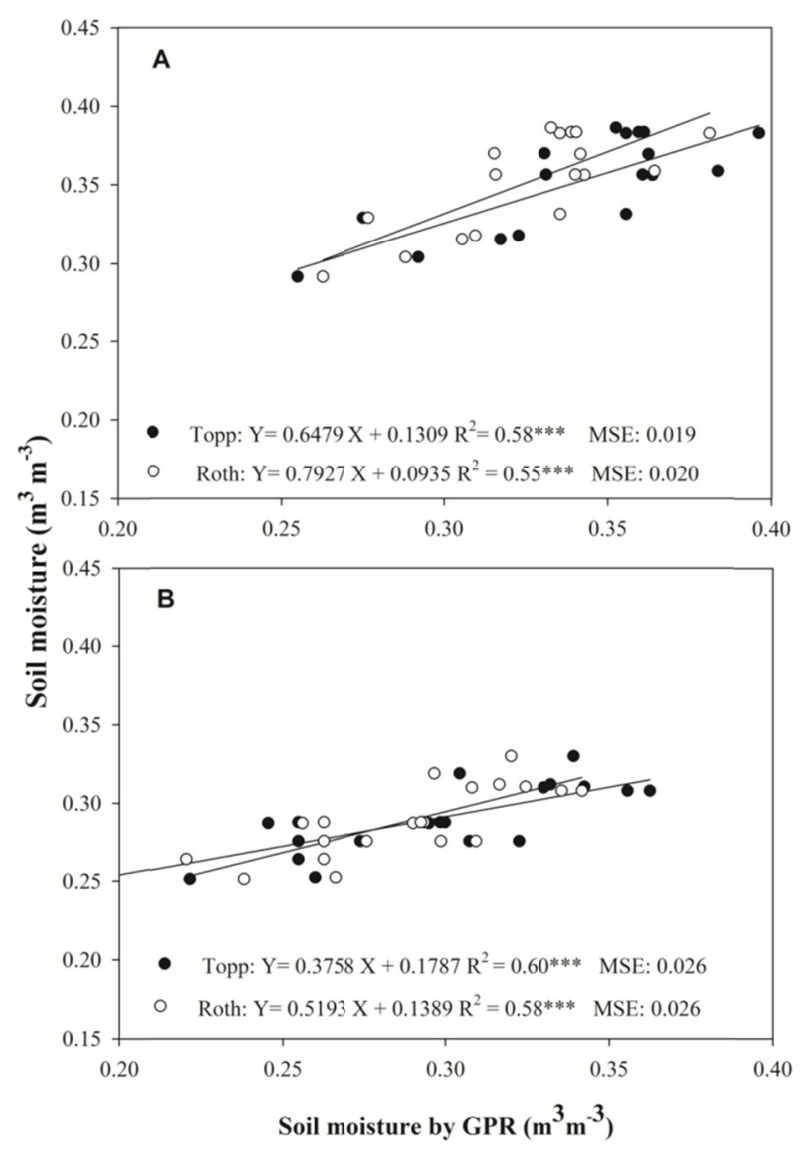

Figure 7. Soil moisture obtained by Ground Penetration Radar (GPR) and estimated by the Topp and Roth equations in a terraced pasture (A) and non-terraced (B). Mean squared error (MSE). Coefficient of determination $\left(\mathrm{R}^{2}\right) * * *$ significant at $0.1 \%$ probability

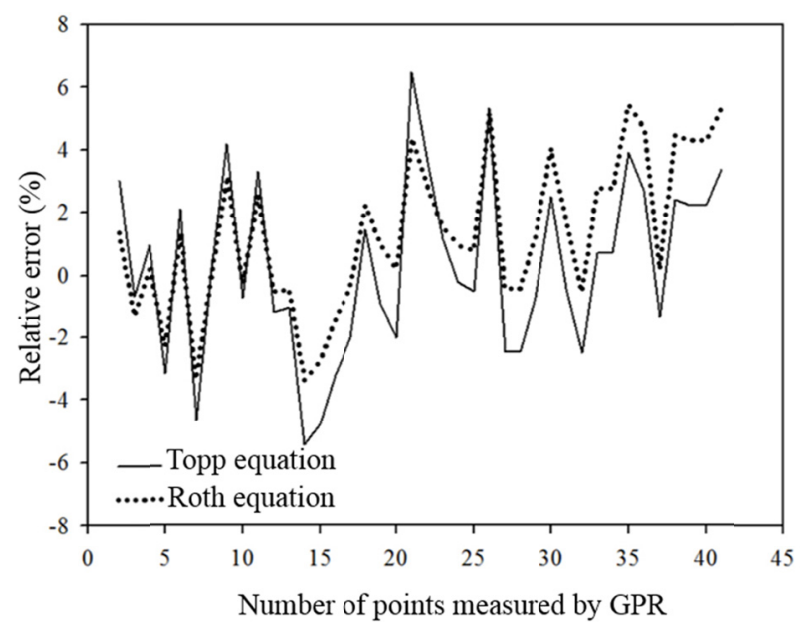

Figure 8 . The relative error of the soil moisture determined by the Topp and Roth equations and Ground Penetration Radar (GPR)

\section{Discussion}

The construction of terraces favors infiltration and increases soil moisture in depth (Querejeta et al., 2000; Zhang et al., 2017). We also observed this increase in soil moisture (up to $24 \%$, Figures 3 to 6). This is because the terraces interrupt the natural slopes, decrease the connectivity and integrity of the terrestrial flow, prolong the residence time of the water, and increase the water infiltration in the soil (Molina et al., 2014). In the studied 
areas, terraces increased soil moisture up to $100 \mathrm{~cm}$ depth (Figure 4). This indicates that the terraces construction is an alternative to raise the water in the soil depth (Huo, 2013). Due to water scarcity in cities, such as Viçosa (Minas Gerais, Brazil), located in the studied watershed, it is crucial to improve the infiltration and storage of water in the soil to supply water sources, especially in the dry season (Ellison et al., 2017). Although the terraced pasture had the highest bulk density that contributed to the greatest microporosity and lowest macroporosity and hydraulic conductivity (Table 2), the soil moisture was highest in Ter. The higher bulk density in Ter (Table 2) suggests a higher soil compaction, due to cattle trampling. Moisture and cover of the soil influenced the amount and quality of forage (field observation), which may have increased the time spent of the animals in the terraced pasture.

According to Chen et al. (2017), despite the increase in soil moisture, the terraced areas do not prevent soil disturbance. Thus, in spite of its benefits, only the use of the terrace is not sufficient for the adequate management of the pastures. Other alternatives should be combined with the terrace to improve soil and water conservation and water dynamics in pastures, especially in mountainous areas (Chen et al., 2017), such as the area of this study. The planting and/or maintenance of trees in pastures is one of these alternatives (Chen et al., 2017). The trees facilitate the water infiltration into the soil, dynamizes the water cycle (Andrade et al., 2015; Ellison et al., 2017), increase recharge of the water source, contributes to the cycling of nutrients and restores vegetation (Zhang et al., 2017).

\subsection{Soil Moisture Dynamics}

The soil moisture in pastures was influenced by rainfall, evapotranspiration and water infiltration in the soil. Rainfall is the only water source in the areas studied.

The high soil moisture variation on the surface (Figures 3 and 6), which was also observed by other authors (Wang et al., 2001; Fu et al., 2003; Gao \& Shao, 2012), shows a sensitivity of this soil layer to rainfall and water evaporation. In addition, the water evaporation has a positive impact on soil moisture up to $25-40 \mathrm{~cm}$ depth (Fu et al., 2003; Sun et al., 2013). This influence, in the data presented here, was up to the $30 \mathrm{~cm}$ layer, especially in the dry season (Figure 6). According to Penna et al. (2009), the soil moisture variation is highest in soil moisture between 23 and 29\%. In this study, this moisture was between 10 and 29\% (Figure 6). More symmetrical distributions, which is characterized by relatively low asymmetry, were found in the wet season, while in the dry season distorted distributions were observed (Figure 6). Hu et al. (2010a) and Wang et al. (2010) showed that soil moisture around $100 \mathrm{~cm}$ depth is stable with intense and continuous rainfall. For other authors, such as Gao and Shao (2012), this stability is up to $300 \mathrm{~cm}$ deep. In our study, the stability occurred in all terraced pasture (Figure 6), which may favor the plant growth (Zhang et al., 2017).

The water accumulation in one meter of depth in the terraced pasture (Figure 5) may explain the highest soil moisture and its uniformity from the $30 \mathrm{~cm}$ of depth in the dry season compared to non-terraced pasture (Figure $6)$.

\subsection{GPR Efficiency}

The coefficients of significant linear correlation were no greatest due to the lack of a standard method for obtaining the dielectric constant (Figure 7). This disadvantage of radargrams may limit the accuracy and the use of GPR to determine soil moisture. The high clay content was another factor that limited GPR analysis (Table 1).

Clay increases the electrical conductivity of soils and limits the soil moisture determination by electromagnetic waves (Huisman et al., 2001). However, in frequencies lower than $300 \mathrm{MHz}$, this determination is significant in clayey soils (White \& Zegelin, 1995).

The mean square error may be considered low (Figure 7). These errors were similar to those found in other studies with conditions similar to ours (Grote et al., 2003; Huisman et al., 2001). In the first study, the soil moisture was obtained using 450 and $900 \mathrm{MHz}$. Huisman et al. (2001) used $450 \mathrm{MHz}$.

Therefore, GPR can provide accurate measurements of soil water content, due to high correlation coefficients and low MSE. However, the equipment is difficult to handle under uneven ground conditions such as ours. GPR is also more costly than the gravimetric method.

The disadvantage of the gravimetric method in relation to GPR is the difficulty of sampling in soil depths.

\section{Conclusion}

The terraced pasture contributed to increasing soil moisture. The water storage in depth was larger and uniform in terraced than in the non-terraced pasture. However, the non terraced pasture has less soil compaction. Thus, 
the terrace does not guarantee adequate pasture management and other alternatives for sustainable management of cattle and reduction of soil compaction is necessary.

The GPR method may be used to estimate the soil water content in volumetric basis in the field of a non-invasive manner. However, there is a need for studies to determine the accuracy of GPR measurement in different soil types and methods.

\section{Acknowledgements}

The authors are very grateful to Brazilian Agencies: CNPq, Capes, and Fapemig for financial support. This study was financed in part by the Coordination for the Improvement of Higher Education Personnel-Brazil (CAPES)-Finance Code 001.

\section{Reference}

Alvarez, V. H. (1999). Interpretation of soil analysis results. In A. C. Ribeiro, P. T. G. Guimarães, \& V. H. Alvares (Eds.), Recommendations for the use of correctives and fertilizers in Minas Gerais state, Brazil: 5th approximation (pp. 289-302). Viçosa, MG: UFV.

Andrade, B. O. (2015). Grassland degradation, and restoration: A conceptual framework of stages and thresholds illustrated by southern Brazilian grasslands. Natureza \& Conservacao, 13(2), 95-104. https://doi.org/ 10.1016/j.ncon.2015.08.002

Chen, D., Wei, W., \& Chen, L. (2017). Effects of terracing practices on water erosion control in China: A meta-analysis. Earth-Science Reviews. https://doi.org/10.1016/j.earscirev.2017.08.007

Dobriyal, P. (2012). A review of the methods available for estimating soil moisture and its implications for water resource management. Journal of Hidrology, 458-459(21), 110-117. https://doi.org/10.1016/j.jhydrol.2012. 06.021

Ellison, D. (2017). Trees, forests and water: Cool insights for a hot world. Global Environmental Change, 43, 51-61. https://doi.org/10.1016/j.gloenvcha.2017.01.002

EMBRAPA. (2011). Centro Nacional de Pesquisa de Solos. In R. J. Embrapa Solos (Ed.), Manual of soil analysis methods (2nd ed., p. 230).

$\mathrm{Fu}, \mathrm{B}$. (2003). The effects of land use on soil moisture variation in the Danangou catchment of the Loess Plateau, China. Catena, 54(1), 197-213. https://doi.org/10.1016/S0341-8162(03)00065-1

Galdino, S. (2015). Large-scale Modeling of Soil Erosion with RUSLE for Conservationist Planning of Degraded Cultivated Brazilian Pastures. Land Degradation \& Development. https://doi.org/10.1002/ $\operatorname{ldr} .2414$

Gao, L., \& Shao, M. (2012). Temporal stability of soil water storage in diverse soil layers. Catena, 95, $24-32$. https://doi.org/10.1016/j.catena.2012.02.020

Germer, S. (2009). Implications of long-termland-use change for the hydrology and solute budgets of small catchments in Amazonia. Journal of Hydrology, 364(3), 349-363. https://doi.org/10.1016/j.jhydrol. 2008.11.013

Gomes, M. A. (2012). Soils, management and hydrological aspects in the Araújos river basin, Viçosa-MG. Revista Árvore, 36(1), 93-102. https://doi.org/10.1590/S0100-67622012000100011

Grote, K., Hubbard, S., \& Rubin, Y. (2003). Field-scale estimation of volumetric water content using ground-penetrating radar ground wave techniques. Water Resources Research, 39(11). https://doi.org/ 10.1029/2003WR002045

$\mathrm{Hu}$, W. (2010a). Watershed scale temporal stability of soil water content. Geoderma, 158(3), 181-198. https://doi.org/10.1016/j.geoderma.2010.04.030

Hu, W., Shao, M., \& Reichardt, K. (2010b). Using a new criterion to identify sites for mean soil water storage evaluation. Soil Science Society of America Journal, 74(3), 762-773. https://doi.org/10.2136/sssaj2009.0235

Huisman, J. A. (2001). Soil water content measurements at different scales: Accuracy of time domain reflectometry and ground-penetrating radar. Journal of Hydrology, 245(1), 48-58. https://doi.org/ 10.1016/S0022-1694(01)00336-5

Huo, Y., \& Zhu, B. (2013). Analysis on the benefits of level terrace on soil and water conservation in loess hilly areas. Research of Soil and Water Conservation, 20(5), 24-28. 
Jerneck, A. (2011). Structuring sustainability science. Sustainability Science, 6(1), 69-82. https://doi.org/ 10.1007/s11625-010-0117-x

Lu, Y. (2017). An Examination of Soil Moisture Estimation Using Ground Penetrating Radar in Desert Steppe. Water, 9(7), 521. https://doi.org/10.3390/w9070521

Mekonnen, M. M., \& Hoekstra, A. Y. (2016). Four billion people facing severe water scarcity. Science Advances, 2(2), e1500323. https://doi.org/10.1126/sciadv.1500323

Molina, A. J. (2014). Spatio-temporal variability of soil water content on the local scale in a Mediterranean mountain area (Vallcebre, North Eastern Spain). How different spatio-temporal scales reflect mean soil water content. Journal of Hydrology, 516, 182-192. https://doi.org/10.1016/j.jhydrol.2014.01.040

Mwendera, E. J., \& Saleem, M. A. (1997). Infiltration rates, surface runoff, and soil loss as influenced by grazing pressure in the Ethiopian highlands. Soil Use and Management, 13(1), 29-35. https://doi.org/10.1111/ j.1475-2743.1997.tb00553.x

Nepstad, D. C., Stickler, C. M., \& Almeida, O. T. (2006). Globalization of the Amazon soy and beef industries: Opportunities for conservation. Conservation Biology, 20(6), 1595-1603. https://doi.org/10.1111/ j.1523-1739.2006.00510.x

Penna, D. (2009). Hillslope scale soil moisture variability in a steep alpine terrain. Journal of Hydrology, 364(3-4), 311-327. https://doi.org/10.1016/j.jhydrol.2008.11.009

Power, A. G. (2010). Ecosystem services and agriculture: Trade-offs and synergies. Phil. Trans. R. Soc. B, 365, 2959-2971. https://doi.org/10.1098/rstb.2010.0143

Querejeta, J. (2000). Soil physical properties and moisture content affected by site preparation in the afforestation of a semiarid rangeland. https://doi.org/10.2136/sssaj2000.6462087x

Roth, C. H., Malicki, M. A., \& Plagge, R. (1992). Empirical evaluation of the relationship between soil dielectric constant and volumetric water content as the basis for calibrating soil moisture measurements by TDR. Journal of Soil Science, 43(1), 1-13. https://doi.org/10.1111/j.1365-2389.1992.tb00115.x

Savadogo, P., Sawadogo, L., \& Tiveau, D. (2007). Effects of grazing intensity and prescribed fire on soil physical and hydrological properties and pasture yield in the savanna woodlands of Burkina Faso. Agriculture, Ecosystems \& Environment, 118(1), 80-92. https://doi.org/10.1016/j.agee.2006.05.002

Shang, Z. H. (2014). The sustainable development of grassland-livestock systems on the Tibetan plateau: Problems, strategies and prospects. The Rangel and Journal, 36(3), 267-296. https://doi.org/10.1071/ RJ14008

Sun, F. (2013). Spatial explicit soil moisture analysis: Pattern and its stability at small catchment scale in the loess hilly region of China. Hydrological Processes, 28(13), 4091-4109. https://doi.org/10.1002/hyp.9940

Tedesco, M. J., Gianello, C., Bissani, C. A., Bohnen, H., \& Wolkweiss, S. J. (1995). Analysis of soil, plants and other materials (2nd ed., p. 174). Porto Alegre, Universidade Federal do Rio Grande do Sul.

Topp, G. C., Davis, J. L., \& Annan, A. P. (1980). Electromagnetic determination of soil water content: Measurements in coaxial transmission lines. Water Resources Research, 16(3), 574-582. https://doi.org/ 10.1029/WR016i003p00574

Wang, J. (2001). Geostatistical analysis of soil moisture variability on Da Nangou catchment of the loess plateau, China. Environmental Geology, 41(1-2), 113-120. https://doi.org/10.1007/s002540100350

Wang, Y., Shao, M., \& Liu, Z. (2010). Large-scale spatial variability of dried soil layers and related factors across the entire Loess Plateau of China. Geoderma, 159(1), 99-108. https://doi.org/10.1016/ j.geoderma.2010.07.001

White, I., \& Zegelin, S. J. (1995). Electric and dielectric methods for monitoring soil-water content. Handbook of Vadose Zone Characterization and Monitoring, 343-385. https://doi.org/10.1201/9780203752524-22

Zhang, H. (2017). Effects of terracing on soil water and canopy transpiration of Pinus tabulaeformis in the Loess Plateau of China. Ecological Engineering, 102, 557-564. https://doi.org/10.1016/j.ecoleng.2017.02.044

Zimmermann, B., Elsenbeer, H., \& Moraes, J. M. (2006). The influence of land-use changes on soil hydraulic properties: Implications for runoff generation. Forest Ecology and Management, 222(1), 29-38. https://doi.org/10.1016/j.foreco.2005.10.070 


\section{Copyrights}

Copyright for this article is retained by the author(s), with first publication rights granted to the journal.

This is an open-access article distributed under the terms and conditions of the Creative Commons Attribution license (http://creativecommons.org/licenses/by/4.0/). 